\title{
Samoobrona i retornantes Następstwa powojennych migracji powrotnych w Andy na przykładzie nielegalnych zasiedleń terenów podmiejskich Ayacucho
}

\begin{abstract}
Abstrakt
Tekst ma charakter studium przypadku. Jego celem jest przyjrzenie się kosztom wojennych przesiedleń i wynikających z nich migracji powrotnych w Andy peruwiańskie na przykładzie rzadko badanego zjawiska w postaci nielegalnych zasiedleń (tzw. inwazji) terenów okalających miasta prowincji. Analiza dotyczy złożonego przypadku akcji zasiedleńczej z udziałem retornantes ${ }^{1}$, przeprowadzonej wiele lat po wojnie przez wywodzące się
\end{abstract}

Adiunkt, politolog, antropolog, Uniwersytet Łódzki, Wydział Studiów Międzynarodowych i Politologicznych, Katedra Studiów Latynoamerykańskich i Porównawczych; e-mail: joanna.pietraszczyk@uni.lodz.pl

1 Retornantes pochodzi od czasownika retornar (z hiszp. „powracać”) i jest używane w Ameryce Łacińskiej w odniesieniu do migrantów powrotnych (zwanych również w jęz. hiszp. migrantes retornados). W tekście stosuję również hispanojęzyczne wersje innych terminów dedykowanych ofiarom konfliktu wewnętrznego. Są to desplazados (z hiszp. „przesiedleni”) oraz afectados, czyli poszkodowani w konflikcie (od hiszp. czasownika afectar, czyli „dotykać”, „wywierać wpływ”). Ponieważ ostatni z terminów wydaje się najbardziej pojemny, stosuję go najczęściej, traktując jako wyraz bliskoznaczny $\mathrm{z}$ pozostałymi, $\mathrm{w}$ tym również tytułowym retornantes. $\mathrm{W}$ tekście używam również polskich pojęć odnoszących się do ofiar konfliktu jak „uchodźcy wewnętrzni”, „uciekinierzy wojenni” czy „reemigranci”. Jest to jednak przykład spolszczenia badanej problematyki, gdyż hiszpański termin refugiado („uchodźca”) nie jest powszechny w Andach w analizowanym kontekście, a pojęcia „reemigrant” nie używa się wcale. 
z jej okresu cywilne sily samoobrony. Podjętym rozważaniom przyświeca teza, iż - przez wzgląd na różnorodność i nieoczywistość uwarunkowań - zachowania migracyjne osób dotkniętych konfliktem zbrojnym stanowią o amorficzności fenomenu powrotów, jak również mogą przyczyniać się do podtrzymania lokalnych kryzysów powstałych w okresie terroru. Część empiryczna tekstu została przygotowana na podstawie prac badawczych zrealizowanych w latach 2004-2010 i 2015-2019 w Limie oraz miastach i terenach wiejskich środkowo-południowych Andów peruwiańskich².

Słowa kluczowe: konflikt wewnętrzny, migracje powrotne, nielegalne zasiedlenia, cywilne siły samoobrony, Peru, środkowo-południowa sierra, Yanama.

\title{
Self-defense and retornantes. The consequences of post-war return migrations in the Andes on the example of illegal settlement of the suburban areas of Ayacucho
}

\begin{abstract}
This paper is a case study with an objective to examine the costs of war displacements and the resulting return migrations to the Peruvian Andes based on the example of scarcely researched illegal settlements (so-called invasions) on the outskirts of towns in the province. The analysis focuses on a complex case of a settlement operation involving retornantes, conducted many years after the war by civil self-defense forces. These considerations are supported by the thesis that - due to the diversity and nonobviousness of the determinants - the migratory behaviors of those affected by the armed conflict account for the amorphism of the phenomenon of returns and may contribute to the perpetuation of local crises which arose during the period of terror. The empirical part of the paper was written based on the results of the research conducted in 2004-2010 and 2015-2019 in Lima as well as in towns and rural areas of the central-southern Peruvian Andes.
\end{abstract}

Keywords: internal conflict, return migrations, illegal settlements, civil self-defense forces, Peru, central-southern sierra, Yanama.

2 Narracja tekstu prowadzona jest w 1. osobie, choć zdaję sobie sprawę, że nie jest to praktyka powszechna w naukach społecznych, w tym także w politologii. Tzw. ujawnianie się autora w tekście występuje natomiast powszechnie we współczesnej antropologii, w ramach której otrzymałam wykształcenie i której narzędzia badawcze dominują wśród tych wykorzystanych w pracy nad artykułem. W przypadku szerokiego zastosowania metody etnograficznej pierwszoosobowa narracja służy m.in. jasnemu rozróżnieniu źródeł wiedzy, szczególnie jeśli tekst zawiera bezpośrednie relacje z badań terenowych. Warto dodać, iż współcześnie zabieg staje się również elementem postępującej antropologizacji nauki, która odbywa się - przede wszystkim - poprzez zapożyczanie przez inne dyscypliny metod i narzędzi badań terenowych; szerzej zob. m.in. A. Posern-Zieliński, Wspólne obszary refleksji: społeczno-kulturowej antropologii, nauk o polityce i nauk prawnych, [w:] A. Pomieciński, S. Sikora (red.), Zanikające granice. Antropologizacja nauki i jej dyskursów, Poznań 2009, s. 103-132; T. Buliński, Czym jest antropologizacja nauk?, [w:] A. Pomieciński, S. Sikora (red.), Zanikające granice. Antropologizacja..., s. 263-277. 
Samoobrona i retornantes. Następstwa powojennych migracji powrotnych...

\section{Wstęp}

Obserwowane od ponad trzech dekad powroty peruwiańskich uchodźców wewnętrznych na tereny środkowo-południowych Andów stanowią wyraźny przykład zjawiska decentralizacji współczesnych procesów migracyjnych. Choć są one bezpośrednim następstwem konfliktu zbrojnego z lat 1980-2000, ich przebieg determinują również regionalne tradycje migracyjne oraz bieżące uwarunkowania polityczne i ekonomiczne, co czyni z nich problem głęboko amorficzny i, tym samym, bardzo trudno mierzalny. W efekcie poszczególne przykłady andyjskich retornos, ich okoliczności i następstwa badane są przede wszystkim z perspektywy jakościowej, najczęściej z uwzględnieniem szerokiego kontekstu historycznego, społeczno-kulturowego i polityczno-ekonomicznego badanego przypadku³ .

Celem niniejszego tekstu jest ukazanie panoramy współczesnych powrotów peruwiańskich uchodźców na tereny andyjskiego wyżu oraz scharakteryzowanie na jej tle specyficznej formy migracji powojennej, jaką stanowią zbrojne zasiedlenia obszarów byłych hacjend okalających miasta, czyli tzw. inwazje retornantes (zwanych szerzej afectados). Podjęte zagadnienia zostaną przeanalizowane zarówno w kontekście bogatych tradycji migracyjnych regionu, jak również znaczenia powojennych problemów społecznych prowincji, wyraźnie nasilonych wraz z trwającymi nadal procesami powrotów: wysokiego poziomu roszczeń politycznych i ekonomicznych ze strony afectados, wyzwań związanych z koniecznością demobilizacji cywilnych grup

\footnotetext{
Szerzej o teorii migracji powrotnych zob. m.in. E. Nowicka, H. Firouzbakch (red.), Homecoming. An Anthropology of Return Migrations, Kraków 2008 oraz D. Niedźwiedzki, Migracje i tożsamość. Od teorii do analizy przypadku, Kraków 2010; a w kontekście Peru: Asociación Pro Derechos Humanos, Los Desplazados. 600000 ciudadanos peruanos sin derechos, Lima 2000, s. 14-27; M. Rodriguez, O. Espinosa (red.), Multiples retornos a una misma tierra. La situación del pueblo Asháninka de los ríos Tambo y Ené - Selva Central, Lima 1997; R. Barrantes, Reparations and Displacement in Peru, ICTJ 2012; N. Zevallos, Desplazamientos Internos en el Perú, Lima 2015 czy G. Yamada, Patrones de migración interna en el Perú reciente, [w:] C. Garavito, I. Muñoz (red.), Empleo y protección social, Lima 2014, s. 91-124.

O powojennych migracjach powrotnych w Andy pisałam również we wcześniejszym tekście (J. Pietraszczyk-Sękowska, Powroty po(do) bliskich. O paradoksach migracji powrotnych i ich związkach z poszukiwaniami desaparecidos $w$ Andach peruwiańskich końca XX i początku XXI wieku, „Ameryka Łacińska” 2020, nr 1, s. 15-38). Choć badany aspekt zjawiska był wówczas zupełnie inny, bo dotyczył powiązań między retornos i poszukiwaniem przez migrantów ich zaginionych bliskich, punkt wyjścia dla obu analiz można uznać za zbieżny. Jest nim dostrzeżenie szeregu czynników wywołujących różnicowanie się fenomenu migracji powrotnych oraz związanych z tym wyzwań metodologicznych.
} 
samoobrony (których siła liczebna oraz uzbrojenie stanowiły przez lata ważną kartę przetargową po stronie poszkodowanych w konflikcie) oraz problemu nieuregulowanych od dekad tytułów własności ziemi, skutkującego po wojnie nawrotem antagonizmów społecznych między byłymi właścicielami hacjend (lub ich spadkobiercami), ludnością chłopską (silnie współcześnie zróżnicowaną i podzieloną) oraz państwem.

W ramach analizy teoretycznej za punkt wyjścia przyjmuję definicję „migracji powrotnej” M. Boyd, zgodnie z którą jest to "powrót do kraju lub obszaru pochodzenia w wymiarze tymczasowym lub długotrwałym"4. W artykule konfrontuję ją z opisem badanego przypadku, w którym kładę nacisk na ukazanie specyficznego, bardzo złożonego charakteru powojennych migracji powrotnych w Andy i ich następstw. Stąd też podjętej analizie przyświecają dwa główne założenia dotyczące cech interesującego mnie fenomenu. Przede wszystkim, przez wzgląd na wielość jego uwarunkowań, postrzegam go jako problem głęboko niejednorodny, którego poszczególne przykłady mogą stanowić oddzielne, w pewnym sensie „samorodne” modele badawcze (tj. słusznie kojarzone $\mathrm{z}$ wojną i powrotami, ale posiadające $\mathrm{z}$ nimi partykularne, często nieoczywiste powiązania) $)^{5}$. Po drugie zakładam, że - jako wynik terroru i przesiedleń - zbrojne inwazje stanowią przedłużenie konfliktu, w tym również w zakresie wygenerowanych przezeń nowych porządków społecznych. Problem ten ukazuję na przykładzie studium przypadku. Dotyczy ono nielegalnej akcji zasiedleńczej, dokonanej w 2006 r. w okolicach miasta Ayacucho przez retornantes prowadzonych przez siły samoobrony cywilnej, które - w okresie wojny „oddelegowane” przez wojsko do stosowania przemocy oraz zarządzania ludnością chłopską - w czasie transformacji powojennej korzystają z obu mandatów tak w destruktywnej, jak i konstruktywnej formie ${ }^{6}$.

Charakterystyka problemu opiera się na analizie literatury przedmiotu i wynikach badań terenowych (obserwacji, wywiadów i lektury wioskowych

4 Cyt. za: K. Romaniszyn, Migration Networks and Return Migration, [w:] E. Nowicka, H. Firouzbakch (red.), Homecoming..., s. 33.

5 Zob. m.in. M. Skoczek, Zmiany mobilności przestrzennej ludności Ameryki Łacińskiej jako efekt globalizacji, [w:] M. F. Gawrycki (red.), Ameryka Łacińska wobec wyzwań globalizacji, Toruń 2006, s. 275-285; M. Rodriguez, O. Espinosa (red.), Multiples...; Asociación Pro Derechos Humanos, op. cit.; F. J. Lozano Martínez, Desplazados por violencia en asentamientos humanos de Huanta y Lima. Perú, Guadalajara 2011; J. Pietraszczyk-Sękowska, Powroty po(do) bliskich...; jak również K. Romaniszyn, op. cit., s. 32-35 oraz D. Niedźwiedzki, op. cit., s. 7-12.

6 Zob. A. Arjona, Wartime Institutions: A Research Agenda, „Journal of Conflict Resolution” 2014, vol. 58, no. 8, s. 1360-1389 oraz M. Fumerton, Beyond Counterinsurgency: Peasant Militias and Wartime Social Order in Peru's Civil War, „European Review of Latin American and Caribbean Studies" 2018, nr 105, s. 62-65. 
archiwaliów) zrealizowanych przeze mnie w 2004 i 2005 r. wśród migrantów andyjskich w Limie oraz w latach 2005-2010/2015-2019 wśród uciekinierów wojennych i retornantes na obszarze departamentu Ayacucho w środkowo-południowych Andach peruwiańskich.

\section{Tło historyczne współczesnych tendencji migracyjnych $\mathrm{w}$ regionie}

Sam zarys dziejów środkowo-południowych Andów peruwiańskich pozwala uznać Ayacucho za „migrujący region”. Zgodnie z powszechną na terenach andyjskich praktyką już kilka tysięcy lat przed naszą erą lokalne społeczności eksploatowały jednocześnie wiele stref klimatyczno-topograficznych ${ }^{7}$, w sposób zasadniczy dywersyfikując tym samym nie tylko własną aktywność gospodarczą, ale również procesy mobilności przestrzennej ludności. W kolejnych epokach wszystkie z dominujących kolejno w regionie kultur ${ }^{8}$ prowadziły dynamiczne akcje osadnicze, które - służąc celom tak gospodarczym, jak i politycznym - nie tylko nadały migracjom charakter w dużej mierze przesiedleńczy, ale również przekładały się na wzrost różnorodności etniczno-kulturowej tej części Andów. Wymienione zjawiska nabrały na znaczeniu i sile w okresie panowania Inków. Tworząc własne ośrodki administracyjne oraz nasilając praktykę przymusowych przesiedleń, władcy imperium prowadzili pacyfikację lokalnych kultur i tym samym budowali dominację w regionie, przez który przebiegały strategiczne dla politycznego i gospodarczego funkcjonowania inkanatu szlaki komunikacyjne z wybrzeża i sierry środkowej do Cuzco 9 .

7 W Ameryce Łacińskiej są one znane jako zonas ecológicas, czyli strefy ekologiczne, które reprezentują bardzo zróżnicowane ekosystemy obszarów wysokogórskich, andyjskich płaskowyżów i dolin czy też wysokiej i niskiej puszczy amazońskiej. Ponieważ wskazana powyżej praktyka eksploatacji kilku ekosystemów przez jedną społeczność jest typowa dla Andów Środkowych, północnoamerykański antropolog J. Murra nazwał te kultury „archipelagami pionowymi” (hiszp. archipiélagos verticales); zob. J. Murra, El mundo andino. Población, medio ambiente y economía, Lima 2014, s. 85-139.

8 Najważniejsze z nich to Warpa, Wari i wywodzące się od tej ostatniej Chanca.

9 Szerzej o okresie prehiszpańskim w omawianym regionie patrz m.in.: T. Tung, Violence, Ritual and the Wari Empire, Gainesville 2012; J. Ochatoma, M. Cabrera, Religión y militarismo en la antigua ciudad Wari, [w:] R. Ayala (red.), Entre la región y la nación. Nuevas aproximaciones a la histora ayacuchana y peruana, Lima 2013, s. 15-48; M. Salas, La ciudad-región de Huamanga: de los tiempos prehispánicos a la era colonial y republicana inicial, [w:] R. Ayala (red.), Entre la región y la nación..., s. 49-84; M. Aguirre, Ayacucho: Vilcashuaman y Cangallo. Gloria y ocaso de una heroica región andina, San Juan de 
Zbliżone determinanty kierowały działaniami obecnych na tym obszarze już od pierwszych lat konkwisty Hiszpanów. Wzrost znaczenia polityczno-militarnego i ekonomicznego oraz rozwój demograficzny założonej w 1539 r. stolicy regionu, Huamangi ${ }^{10}$, działać miał wielokierunkowo: wzmacniać ważny ośrodek handlowy na szlaku łączącym sierrę środkowo-południową z wybrzeżem, otwierać stosunkowo dogodną drogę dostępu do selwy, sprzyjać rozwojowi niezbędnej dla aprowizacji Limy produkcji rolnej i hodowlanej oraz stanowić jednocześnie administracyjną i militarną przeciwwagę dla Cuzco (posiadającego jeszcze przez wieki największy potencjał tubylczego buntu przeciwko systemowi kolonialnemu). Podobnie jak w innych rejonach Andów, realizacja tych założeń przełożyła się na znaczne nasilenie zjawiska mobilności przestrzennej mieszkańców, na które złożyły się zarówno przymusowe przesiedlenia w granice nowo tworzonych tubylczych osad (tzw. redukcji) i cykliczna wymiana pracowników w ramach systemu pracy przymusowej (tzw. mity), jak również migracje ekonomiczne i ucieczki ludności rdzennej przed obciążeniami osobistymi (zarówno dotkliwym trybutem, jak i wspomnianą mitą) z terenów wspólnot do miast ${ }^{11}$.

Zasadnicze zmiany wywołała sytuacja z przełomu XIX i XX w., gdy zapóźnienia w niewydajnym rolnictwie (którego rozwój i modernizację ograniczał zarówno feudalizm, jak i skromny areał uprawny w regionie) zaczęły przekładać się na pierwsze oznaki długotrwałego kryzysu gospodarczego i - będące jego bezpośrednią konsekwencją - zapowiedzi poważnych przemian społecznych. Choć w latach 1940-1980 w wielu regionach Peru trwał boom demograficzny, w Ayacucho przyrost ludności był bardzo powolny. Populacja departamentu wzrosła wówczas z czterystu do pięciuset tysięcy (czyli o $1 / 4$, podczas gdy w innych regionach potrafiła się podwoić), charakteryzując się jednocześnie wysokim współczynnikiem odpływu ludności ze wsi do miast, w tym głównie ośrodków miejskich sierry i wybrzeża, ale również intensywnie kolonizowanej wówczas selwy. Postęp urbanizacji prowincji był wynikiem zarówno gospodarczej zapaści hacjend (która wywołała masowe ucieczki pracowników rolnych przed wzrostem nakładanych na nich obciążeń), ale również boomu edukacyjnego związanego z ponownym otwarciem

Miraflores 2008, s. 25-166; A. Valesco Zapata, N. Chávez Pereyra, R. Rojas Rojas (red.), Historia y cultura de Ayacucho, Lima 2010, s. 53-81.

10 Pełna nazwa miasta z okresu jego fundacji to San Juan de la Frontera de Huamanga.

11 Szerzej: V. Roel, Historia social y económica de la colonia, Lima 1999, s. 89-120; N. E. Pereyra, Élite, poder y disciplina en el Perú temprano colonial: el caso de Huamanga, 15391550, [w:] R. Ayala (red.), Entre la región y la nación..., s. 85-103; P. Kláren, Nación $y$ sociedad en la historia del Perú, Lima 2004, s. 60-82. 
$\mathrm{UNSCH}^{12}$ oraz znacznym przyrostem liczby szkół średnich w ośrodkach miejskich regionu. Procesy odpływu ludności $z$ andyjskich wiosek wyhamowała $\mathrm{w}$ ograniczonym zakresie reforma rolna $\mathrm{z}$ końca lat 60 . XX w. ${ }^{13} \mathrm{Nie}-$ mniej, dekadę później doszło do wyraźnej eskalacji problemu w wyniku nasilenia i brutalizacji działań zbrojnych na terenach wiejskich.

Wojna domowa z lat 1980-2000 objęła swym zasięgiem 16 z 24 departamentów, niemniej zaczęła się w Ayacucho, które - wraz z sąsiadującymi z nim regionami - do końca konfliktu pozostało epicentrum działań militarnych. Choć konfrontacja strony rządowej z siłami rewolucyjnymi miała charakter walki o władzę w państwie i wpisywała się w mechanizmy zimnowojenne, jej koszty społeczne poniosła przede wszystkim ludność chłopska pochodzenia tubylczego, apriorycznie identyfikowana $z$ komunizmem i uznana w ten sposób za „naturalnego” sojusznika Świetlistego Szlaku. Skalę ofiar wojny domowej zwiększył zasadniczo fakt uwikłania w działania militarne tysięcy mieszkańców prowincji, którzy - dziesiątkowani tak przez formacje państwowe, jak i organizacje antyrządowe - podjęli samoobronę, stając się wkrótce jednym $\mathrm{z}$ aktorów zbrojnych konfliktu. Tworzone nieformalnie niemal od początku wojny siły chłopskie już pod koniec lat 80. odgrywały znaczną rolę w pacyfikacji terenów wiejskich, by na początku kolejnej dekady zostać częścią tzw. rządowej strategii antywywrotowej i działać już wówczas oficjalnie pod nazwą Komitetów Samoobrony (hiszp. CAD’s). Choć wiele $\mathrm{z}$ nich powstało pierwotnie $\mathrm{w}$ akcie obronnym andyjskich wiosek, wraz z postępem „sojuszu” z siłami rządowymi zaczęły wyraźnie przyczyniać się do wzrostu kosztów społecznych walk na prowincji. Nie tylko eskalowały bratobójczy charakter wojny domowej, wywołując przy tym znaczne straty we własnych szeregach (tak ze względu na brak przygotowania militarnego i słabe uzbrojenie, jak również podatność na nadużycia ze strony wojska),

12 Hiszp. Universidad Nacional de San Cristóbal de Huamanga (Uniwersytet Narodowy św. Krzysztofa w Huamandze). Jest to druga najstarsza uczelnia w Peru; założona w roku 1677 i zamknięta pod koniec XIX w. w warunkach kryzysu polityczno-gospodarczego. Jej reaktywacja w latach 50 . XX w. nie tylko oznaczała prawdziwy rozkwit środowiska akademickiego na terenie środkowo-południowej prowincji, ale również wprowadziła do jej życia publicznego zupełnie nowe nurty światopoglądowe; szerzej o UNSCH: C. I. Degregori, El surgimiento de Sendero Luminoso. Ayacucho 1969-1979, Lima 2010, s. 37-48; R. Cavero, UNSCH „... imposible es morir”. Universidad satanizada, asfixiada y violentada, Huancayo 2005; A. Zapata, N. Pereyra, R. Rojas (red.), Historia y cultura..., s. 159-165.

$13 \mathrm{O}$ społecznych konsekwencjach reformy rolnej oraz zmian $\mathrm{w}$ edukacji patrz m.in.: E. Mayer, Cuentos feos de la reforma agraria peruana, Lima 2017; A. Zapata, N. Pereyra, R. Rojas (red.), Historia y cultura..., s. 159-182; P. Kláren, op. cit., s. 393-428; C. I. Degregori, El surgimiento de Sendero..., s. 49-67. 
ale również nasilały zjawisko przesiedleń. To ostatnie wymaga szczególnego podkreślenia, bo stanowi jeden $z$ tragicznych paradoksów peruwiańskiego konfliktu. Zyskując coraz większą autonomię i totalizując walkę ze Świetlistym Szlakiem, siły chłopskie miały również swój udział w procesach wyludniania się prowincji, na które złożyły się tak ucieczki mieszkańców z grabionych wspólnie przez wojsko i CAD’s wiosek, jak i przymusowe przesiedlenia ludności chłopskiej do tzw. baz antywywrotowych jako rządowych form jej izolacji od senderyzmu ${ }^{14}$.

W wyniku wskazanych mechanizmów konflikt wewnętrzny dokonał na prowincji nieodwracalnych zniszczeń. Oprócz masowych mordów, których ofiarą była w $80 \%$ ludność wiejska, praktykowanych na niej tortur, zaginięć i gwałtów oraz dewastacji setek wiosek wielopostaciowa przemoc wywoływała kolejne fale ucieczek. Powstałe w ten sposób masowe zjawisko uchodźstwa wewnętrznego przez lata rozwijało się jednak w tle przybierających coraz większe rozmiary działań zbrojnych, przez co nigdy nie poznano jego rozmiarów. Nie dostrzeżono również jego istoty, mimo iż wyraźnie stanowiło eskalację konfliktu w czasie i przestrzeni. Choć liczbę ofiar śmiertelnych wojny próbowano określić bardzo dokładnie, szacunki dotyczące uciekinierów pozostały przez lata tak rozbieżne, że po dziś dzień utrudniają konceptualizację tematu jako problemu badawczego. Dopiero pod koniec konfliktu wyliczono, że w latach 1980-1997 w wyniku działań zbrojnych zostało przesiedlonych około 430000 osób. Nieco później instytucje pomocowe ustaliły, że jedynie w latach 1983-1992 było w Peru 600000 uciekinierów wojennych. Oznacza to, że w ciągu dwóch dekad wojny ucieczkę z miejsca zamieszkania mógł podjąć nawet milion Peruwiańczyków ${ }^{15}$. Niepokojące szacunki, co do

14 Szerzej o konflikcie w Peru patrz m.in: G. Gorriti, Sendero Luminoso. Historia de la guerra milenaria en el Perú. Tomo I, Lima 1990; C. I. Degregori, Sendero Luminoso. I. Los hondos y mortales desencuentros, II Sendero Luminoso: lucha armada y utopía autoritaria, Documento de Trabajo n. 4 y 6, Lima 1985; C. Tapia, Las Fuerzas Armadas y Sendero Luminoso, Lima 1997; N. Manrique, El tiempo del miedo. La violencia política en el Perú 1980-1996, Lima 2002; E. Jiménez, Chungui. Violencia y trazos de memoria, Lima 2009; a o specyfice chłopskiej samoobrony: C. I. Degregori (red.), Las rondas campesinas y la derrota de Sendero Luminoso, Lima 1996; M. Fumerton, Rondas Campesinas in the Peruvian Civil War: Peasant Self-Defence Organisations in Ayacucho, „Bulletin of Latin American Research" 2001, vol. 20, no. 4, s. 470-497 oraz J. Pietraszczyk, Peruwiańskie Komitety Samoobrony - w poszukiwaniu nowej roli społecznej, [w:] M. Kania, A. Kaganiec-Kamieńska (red.), Doświadczenie demokracji w Ameryce Łacińskiej, Kraków 2008, s. 75-88.

15 Dane na podstawie: Mesa nacional sobre desplazamiento, Balance del proceso de desplazamiento por violencia política en el Perú (1980-1997), „Amérique Latine Histoire et Mémoire. Les Cahiers ALHIM” 2002, no. 5; Asociación Pro Derechos Humanos, 
skali przesiedleń, jak i wielu innych kosztów społecznych konfliktu oznaczały, że readaptacja mieszkańców do życia na terenach prowincji przez wiele kolejnych lat odsłaniała nowe oblicza następstw wojny. Jak się okazało, należał do nich również nieoczywisty wcześniej związek między skomplikowanym charakterem powrotów afectados oraz stale nieuregulowanym statusem grup wioskowej samoobrony (których aktywność przez znaczną część powojnia rosła w siłę, czemu sprzyjał m.in. regularnie przywracany w Andach stan wyjątkowy).

\section{Morfologia powrotów}

Złożone mechanizmy rozwoju działań zbrojnych na prowincji oraz wielowymiarowość ich kosztów społecznych sprawiły, że na przestrzeni niemal całego konfliktu wydawało się, iż mieszkańcy środkowo-południowej sierry są w ciągłym ruchu. W efekcie ich nasilone - choć niejednorodne tak w wymiarze czasowym i przestrzennym, jak i demograficznym - zachowania migracyjne zaczęły wyraźnie odbiegać od ich prostych modeli teoretycznych. Oznaczało to nie tylko zaburzenie jednokierunkowej (w teorii) trasy migracji przesiedleńczej i powrotnej, ale nawet zacieranie się granicy między zjawiskiem ucieczki i powrotu. Te same procesy sprawiły również, iż wizerunek zewnętrzny migrantów z terenów dotkniętych konfliktem uległ homogenizacji w ramach wspólnej kategorii afectados. Przebywając w obcym środowisku byli nadal łatwo identyfikowani jako przybysze $\mathrm{z}$ epicentrum wojny domowej, ale już znacznie trudniej jako desplazado, retornante czy ewentualnie inna kategoria Obcego ${ }^{16}$.

Niejednorodność i wyraźna tymczasowość zachowań uciekinierów wojennych wynikały głównie z faktu, iż przesiedlenie ze strefy konfliktu stanowiło prolongację doświadczenia przemocy. Jak łatwo się domyślić, w przyjmujących ich społecznościach miejskich - bez większych wyjątków - funkcjonowali w trudnych warunkach bytowych, którym towarzyszył brak społecznej akceptacji. Nie tylko jako „zwykli” obcy, ale w dodatku obcy kojarzeni

op. cit., s. 9-18; M. Śniadecka-Kotarska, Kobiety w migracjach przesiedleńczych w Peru (1980-2000), „Środkowoeuropejskie Studia Polityczne” 2006, nr 1, s. 49-51; F. J. Lozano Martínez, op. cit., s. 43-44; Comisión de la Verdad y Reconciliación, Hatun Willakuy. Versión abreviada del Informe Final de la CVR, Lima 2008, s. 386.

16 O „rozmyciu” kategorii migracyjnych zob. m.in. K. Romaniszyn, op. cit., s. 32-39; a w odniesieniu do badanego przypadku: Asociación Pro Derechos Humanos, op. cit., s. 14-34; N. Zevallos, op. cit., s. 13-50; F. J. Lozano Martínez, op. cit., s. 9-53; R. Barrantes, op. cit., s. 5-9 oraz moje badania w roku 2010 na terenie inwazji „Yanama” w Ayacucho i w latach 2015-2019 w strefie Putis na wyżu Huanty. 
z terroryzmem, padali ofiarą stygmatyzacji i dyskryminacji, które były jednoznaczne $\mathrm{z}$ odmawianiem im równoprawnej pozycji w społeczeństwie ${ }^{17}$. Około dziesięciogodzinny dzień pracy; nisko płatne, nieobjęte systemem socjalnym zajęcia (w tym głównie prace fizyczne i handel uliczny); duża odległość między miejscem zamieszkania i miejscem zatrudnienia oraz związane z tym wielogodzinne dojazdy przekładały się na trudności budżetowe, dysfunkcje rodziców odpowiedzialnych za dorastające w obcym środowisku dzieci, zaniedbywanie przez te ostatnie edukacji, nasilenie się zjawiska przemocy domowej i, w efekcie, dekompozycję rodzin. Co więcej, choć nie ma wątpliwości, iż żyjącym w podobnych warunkach uchodźcom towarzyszył nieodłącznie brak poczucia bezpieczeństwa, warto pamiętać, że problem ten generowało nie tylko wyobcowanie i rosnący wówczas w ośrodkach miejskich poziom przestępczości. Nie bez znaczenia były również uwarunkowania ekologiczne: zanieczyszczenie środowiska i brak dostępu do ziemi uprawnej (jako podstawowego dotąd źródła wyżywienia rodziny), które przekładały się nie tylko na dyskomfort psychiczny, ale także fizyczny. W ich efekcie, mimo pozornie większego dostępu do medycyny i farmakologii, szukających schronienia $\mathrm{w}$ miastach afectados dziesiątkowały problemy zdrowotne ${ }^{18}$.

Przez wzgląd na wskazane czynniki, pierwsze próby powrotów uchodźców wewnętrznych do wiosek ich pochodzenia miały miejsce już w II połowie lat 80. Jako, de facto, ucieczki przed wyzyskiem i trudnymi warunkami

17 Szerzej o mechanizmach przemocy kulturowej wobec andyjskich uciekinierów wojennych w miastach zob. M. Śniadecka-Kotarska, op. cit., s. 52-58.

18 Wszyscy współpracujący ze mną afectados, którzy trafili w okresie wojny do Limy, zwrócili uwagę, że jednym z powodów ich finalnej decyzji o powrocie na prowincję był brak przestrzeni i zanieczyszczenie środowiska w stolicy, które przekładały się na częste zachorowania tak dorosłych, jak i dzieci. Warto pamiętać, że doświadczenia te wiązały się w znacznym stopniu z sygnalizowanym powyżej problemem uciążliwych dojazdów do pracy i szkoły. Przez wzgląd na fakt, iż andyjscy uciekinierzy trafiali najczęściej do nowo powstałych dzielnic okalających miasto (czyli tzw. conos, co z hiszp. oznacza „stożki” i sugeruje ich kształt na tle pustynno-wyżynnych okolic Limy), czas ich przebywania w środkach transportu zbiorowego mógł wynosić nawet 3-4 godziny dziennie (pod koniec wojny populacja stolicy urosła do blisko $10 \mathrm{mln}$ mieszkańców, a rozpiętość jej obszaru z północy na południe sięgnęła $70 \mathrm{~km}$ ). Z biegiem lat do wyzwań ekologicznych dołączył problem z dostępem do wody pitnej, której niedostatki mogą współcześnie zdecydować o wyludnianiu się metropolii. Kilkoro respondentów stwierdziło, że szok, jaki wywołały u nich warunki życia w stolicy i przerwy w dostawach wody, skłonił ich do przeniesienia się "na łono natury” w selwie (czyli ekosystem skrajnie odmienny tak od suchego wybrzeża, jak i surowej sierry); na podstawie rozmów z poszkodowanymi w konflikcie zamieszkałymi w Limie (lata 2004-2005) oraz w Ayacucho i Huancie (lata 2007-2010 i 2015-2016). 
życia w miastach, inicjatywy te niewolne były jednak od czynnika przymusu i charakteryzowały się brakiem strategii przetrwania na zniszczonych lub objętych nadal walkami terenach wiejskich. Stąd też już kilka lat później w działaniach uciekinierów wojennych zaczęły przeważać wysiłki na rzecz bezpiecznego przebiegu migracji powrotnych. Oznaczało to ich gotowość do współpracy z państwem, które na początku dekady lat 90. uruchomiło pierwsze odgórne programy ponownego zaludniania i rekonstrukcji prowincji. Co ważne, wsparcie aktu powrotu przez administrację państwową wiązało się $\mathrm{z}$ zastosowaniem modelu bezpieczeństwa wiosek powstałego $\mathrm{w}$ okresie wojny. Było to jednoznaczne $\mathrm{z}$ obowiązkiem podjęcia inicjatywy w dużej, zorganizowanej grupie retornantes, posiadania przez nią własnych sił samoobrony oraz podporządkowania tych ostatnich formalnej kontroli wojska, które oceniało stan bezpieczeństwa prowincji i, następnie, konwojowało społeczność w czasie jej wędrówki w rejon pochodzenia ${ }^{19}$.

Ponieważ od pierwszej połowy lat 90. napływ uchodźców na tereny środkowo-południowej sierry wyraźnie narastał, podobną tendencję uznano za podyktowaną przede wszystkim sentymentalnym motywem powrotu w rodzinne strony i związaną z nim możliwością życia oraz wychowania dzieci we własnym kręgu kulturowym. Niejednolity przebieg wędrówek afectados do miejsc ich pochodzenia pokazał jednak, że kierowały nimi różne motywacje, a sam akt powrotu - inaczej niż się spodziewano - niekoniecznie wiązał się $\mathrm{z}$ decyzją o pozostaniu $\mathrm{w}$ rodzinnych stronach na stałe. Podobnie jak miało to miejsce w latach 80. duża część "powrotów” okazywała się początkiem wieloetapowej, zupełnie nieoczywistej trasy migracji. Po epizodzie pobytu w rodzinnej wiosce, skutkującym bardzo często rozczarowaniem niskim poziomem bezpieczeństwa na prowincji oraz nieumiejętnością readaptacji do życia w Andach, migranci zabezpieczali swoją własność na wsi i, nomen omen, wracali do poszukiwania stałego miejsca zamieszkania wśród lokalizacji znanych im z okresu ucieczki ${ }^{20}$ (lub, ewen-

19 Szerzej: R. Barrantes, op. cit., s. 5-12; Asociación Pro Derechos Humanos, op. cit., s. 1618, 31-40; Mesa nacional sobre desplazamiento, op. cit; F. J. Lozano Martínez, op. cit., s. 24, 43-48 oraz moje badania wśród afectados w Huancie (listopad 2007, styczeń 2010), na wyżu Chaki (styczeń 2009) oraz strefie Putis (październik 2015, czerwiec 2016 i maj 2019).

20 Co de facto oznaczało, że kilkuetapowa trasa "powrotu” stanowiła nierzadko jedynie modyfikację równie złożonej trasy przesiedlenia (biegnącej najczęściej przez kolejne wioski sierry, tzw. bazy antywywrotowe oraz ośrodki miejskie prowincji i, następnie, duże miasta wybrzeża lub ewentualnie względnie bezpieczne lokalizacje na terenie selwy). W 2020 r. pisałam o migracjach powrotnych w Andy w kontekście jeszcze innego ich motywu, jakim była niemal od początku wojny (i przez wzgląd na trwające 
tualnie, kierunków zupełnie nowych). Zgodnie z ich relacjami podobne decyzje wynikały głównie $\mathrm{z}$ chęci zapewnienia rodzinie wyższego poziomu życia i lepszych warunków rozwoju w ośrodkach miejskich ${ }^{21}$. Co ważne, zdecydowana większość afectados nie rezygnowała przy tym jednak z cyklicznych powrotów do wiosek pochodzenia; nie tylko jako "ziem ojców”, ale także lokalizacji gospodarstw (w których podtrzymywano produkcję żywności) czy nawet miejsc wychowania najmłodszych, nieobjętych jeszcze edukacją gimnazjalną dzieci (które w podobnej sytuacji pozostawały na wsi z matką lub najbliższymi krewnymi, niejako chronione w ten sposób przed środowiskiem miejskim).

Jak łatwo się domyślić, podobne różnicowanie się zachowań migracyjnych pisało odmienne scenariusze losów zarówno rodzin, jak i całych społeczności retornantes, przekładając się wkrótce na poważne utrudnienia w parametryzacji zjawiska migracji powrotnych. W obserwacji problemu istotną rolę odegrał również sygnalizowany już fakt, iż powroty inicjowane w latach 80. rozgrywały się na tle mających nadal miejsce ucieczek oraz wędrówek ekonomicznych, co utrudniało śledzenie ich przebiegu. W efekcie badania procesów powrotów w Andy rozpoczęto stosunkowo późno, skupiając się przy tym przede wszystkim na jakościowych studiach przypadku. Stąd też współcześnie brakuje na ich temat danych liczbowych, a tworzone statystyki dotyczą najczęściej wybranej kategorii powrotu lub też konkretnej fali migra-

współcześnie ekshumacje w pewnym sensie nadal pozostaje) potrzeba poszukiwania zaginionych bliskich, tzw. desaparecidos. Był to kolejny czynnik silnie różnicujący mobilność przestrzenną poszkodowanych w konflikcie, gdyż w praktyce oznaczał wiele "powrotów” w rodzinne strony i, następnie, przemierzanie ich rozległych okolic celem lokalizowania anonimowych mogił zaginionych krewnych; zob. J. Pietraszczyk-Sękowska, Powroty po (do) bliskich...

${ }^{21}$ W świetle wypowiedzi moich rozmówców źródła tych decyzji wydają się na tyle oczywiste i niemal zawsze zbieżne, że trudno z nimi dyskutować. Dominuje wśród nich potrzeba dostępu do miejskiego rynku pracy, transportu publicznego, opieki zdrowotnej oraz, co szczególnie podkreślane, lepszej edukacji dla dzieci. To ostatnie warto ukazać na przykładzie wypowiedzi lidera CAD’s, która rysuje szerszy obraz położenia andyjskich retornantes w powojennym Peru: „Edukacja. To jest jedyny sposób, by w Peru coś się zmieniło. A na wsi nasze dzieci mają mizerne warunki. W wioskach są jedynie szkoły podstawowe z bardzo złym poziomem. Do średniej trzeba dziecko wysłać do większego ośrodka lub do miasta. A pokój w Ayacucho to 80 soli miesięcznie. I jeszcze utrzymanie. W dodatku, jeśli one są w mieście same, to się narkotyzują, prostytuują, kradną... Chodziło nam o to, żeby nasze dzieci mogły pójść do lepszej szkoły, bo dzieci chłopskie są bystre, tylko szkoła wiejska nie daje im żadnych szans w konkurencji z miastem” (rozmowa z Estebanem Quispe Campą [alias „Centurión”], więzienie Yanamilla, Ayacucho, 9 stycznia 2010). 
cji w danym regionie środkowo-południowej sierry ${ }^{22}$. Dlatego też najprostszą formą podziału fenomenu wydaje się wskazana powyżej kategoryzacja czasowa na retornos podejmowane oddolnie od II połowy lat 80 . i te wspierane odgórnie przez władze centralne od początku lat 90 . Niemniej, również w jej przypadku należy pamiętać, iż peruwiańskie państwo zdecydowanie nie zdołało utrzymać funkcji regulatora depopulacji miast i służącej jej polityki powrotów, które leżały u źródeł formalnego zaangażowania się rządu A. Fujimoriego w pomoc poszkodowanym w konflikcie. W efekcie, choć trwające od początku lat 90. retornos były często inicjatywą władz i obarczone zostały szeregiem wymogów formalnych wobec migrantów, to jednak ich przebieg i skutki w znacznej mierze wymknęły się kontroli instytucji państwowych.

\section{Retornos a zjawisko inwazji}

Wśród różnych porządków migracji powrotnych ukształtował się jeden w sposób szczególny podtrzymujący przemoc z okresu konfliktu. Jego źródeł należy szukać przede wszystkim na terenach dotkniętych wielostronnym terrorem, gdzie po epizodzie powrotu do wiosek pochodzenia ludność chłopska podejmowała decyzję o organizacji zbiorowego zasiedlenia (tzw. inwazji) ziem byłych hacjend usytuowanych w pobliżu andyjskich miast. W ten sposób migracja retornantes przebiegała co najmniej dwuetapowo. Pierwszy z etapów opierał się najczęściej na współpracy uchodźców z instytucjami państwowy$\mathrm{mi}, \mathrm{z}$ których pomocą dochodziło do ponownego zaludnienia porzuconych w okresie wojny wiosek oraz prób ich odbudowy w ramach uruchamianych powoli przez władze programów pomocowych. W drugim - ze względu na istniejące nadal na prowincji zagrożenia, ogromną skalę zniszczeń wojennych oraz rozczarowanie warunkami bytowymi w wioskach (i wyraźnie ograniczoną dostępnością środków na ich odbudowę) - lokalni liderzy podejmowali decyzję o reorganizacji własnych społeczności w ramach stowarzyszeń ofiar konfliktu i poszukiwania pod ich szyldem nowych ziem pod zasiedlenie. Ponieważ celem afectados było opuszczenie pozbawionych infrastruktury, rozproszonych po rozległym andyjskim wyżu wiosek, przedmiotem ich zainteresowania stawały się niemal wyłącznie tereny podmiejskie, w tym głównie nieużytki lub ziemie o nieuregulowanym statusie prawnym (czyli charakterystyczne dla obszarów byłych hacjend). Co wymaga podkreślenia, akcje

22 Na temat prób tworzenia szacunków liczbowych dotyczących retornantes patrz m.in.: Mesa nacional sobre desplazamiento, op. cit.; Asociación Pro Derechos Humanos, op. cit., s. 31-34; F. J. Lozano Martínez, op. cit., s. 43-48; Comisión de la Verdad y Reconciliación, op. cit., s. 386-388. 
zasiedleńcze podejmowano pod hasłem konieczności spłaty przez państwo wojennego długu zaciągniętego wśród andyjskich chłopów poprzez ich zaangażowanie do walki z senderyzmem. Stąd też podobne inicjatywy miały często charakter zbrojny, a na ich czele stawały siły chłopskiej samoobrony (czyli wspomniane wcześniej CAD’s). Wśród szeregu konsekwencji, inwazje retornantes powodowały eskalację jednego z najważniejszych problemów społecznych w Andach, tj. wielopłaszczyznowych konfliktów o ziemię, których nie zdołała rozwiązać dedykowana im reforma rolna z końca lat 60 . W trakcie konfliktu zbrojnego wiele $\mathrm{z}$ nich uległo pogłębieniu (lub ewentualnie czasowemu uśpieniu), by w okresie powojennym okazać się swoistym katalizatorem niewolnych od przemocy rywalizacji politycznych i społecznych oraz związanych z nimi sądowych dysput o tytuły własności ziemi ${ }^{23}$.

Mechanizm i konsekwencje problemu analizuję na przykładzie zbadanego przeze mnie "przypadku Yanamy”. Dotyczy on aktu zbrojnego zasiedlenia południowych rubieży miasta Ayacucho, dokonanego w 2006 r. przez pochodzących z różnych regionów prowincji retornantes, zreorganizowanych i prowadzonych przez współpracujące ze sobą siły CAD's' ${ }^{24}$. Liczący 360 ha obszar Yanamy to tereny dawnej hacjendy o tej samej nazwie. Lokalna, tubylcza rodzina Quispe wykupiła ją już w latach 30. XX w. od właścicieli ziemskich, dla których pracowała. W czasie reformy rolnej z przełomu lat 60. i 70. w przypadku ziem Yanamy zastosowano jedną z najbardziej powszechnych wówczas metod restrukturyzacji własności, tj. podział między spadkobierców jej ostatniego nabywcy (w tym wypadku było to pięcioro wnucząt pierwszego właściciela z rodziny Quispe, Maksymiliana Huashuayo). Ze względu na rozdrobnienie własności, w kolejnych latach formy użytkowania ziem były różne, niemniej na części z nich utworzono chacry ${ }^{25}$ i podtrzymano produkcję rolną, którą kontynuowano również w okresie wojny domowej. Narastający

23 Na podstawie badań w mieście Ayacucho i Huancie oraz na terenie pobliskich inwazji „Yanama” i „Aykas” w styczniu 2009 r., styczniu 2010 r., październiku 2015 r. oraz czerwcu 2016 r.

24 „Kazus Yanamy” zainteresował mnie już w latach 2009-2010 w czasie badań do doktoratu, w którym poświęciłam mu niewielki fragment dotyczący powojennej aktywności CAD’s (J. Pietraszczyk-Sękowska, Peruwiańskie siły samoobrony chłopskiej. Od konfliktu zbrojnego do transformacji pokojowej, t. II, Poznań 2011, s. 152-153 maszynopisu). Udało mi się wówczas spotkać zarówno z przedstawicielką poszkodowanej rodziny, jak i liderem akcji, „Centuriónem”, osadzonym już wtedy w więzieniu. Wiele kluczowych informacji zdobyłam jednak kilka lat później, gdy mechanizmy działania sił chłopskich oraz powstania osiedla nie były już tak silnie tabuizowane, dzięki czemu mogłam bez większych problemów przebywać na terenie „Yanamy” i prowadzić rozmowy z jej władzami.

25 Chacra to termin pochodzący z jęz. keczua i oznaczający parcelę rolną. W praktyce jest to najczęściej obszar upraw lub hodowli, w obrębie którego znajduje się również prosta 
terror Świetlistego Szlaku, który dotknął także rodzinę Quispe jako nowych gamonali ${ }^{26}$, sprawił jednak, że w latach 80 . właściciele Yanamy przenieśli się do miasta Ayacucho, a tereny uprawne wizytowali okazjonalnie, przede wszystkim w czasie zbiorów.

W latach 2003-2004, czyli niedługo po zakończeniu konfliktu wewnętrznego, terenami Yanamy zainteresowali się poszukujący nowego miejsca zamieszkania afectados. Była to grupa kilku tysięcy osób wywodzących się ze społeczności najbardziej dotkniętych konfliktem i w zdecydowanej większości w jego wyniku przesiedlonych. Co ważne, choć migranci pochodzili z różnych departamentów środkowo-południowej prowincji (tj. nie tylko Ayacucho, ale także Huancaveliki i Junín), większość z nich łączyło doświadczenie nieudanego powrotu do wiosek pochodzenia, w następstwie którego podjęli wspólny wysiłek wyszukania i zasiedlenia terenów podmiejskich ${ }^{27}$. Co wymaga podkreślenia, na ich czele stali doświadczeni liderzy chłopskich sił samoobrony, których intencją była nie tylko integracja zebranej grupy jako społeczności rodzin poszkodowanych w konflikcie, ale także dalsza rozbudowa jej szeregów służąca osiąganiu wspólnych celów drogą manifestacji siły ${ }^{28}$.

zabudowa gospodarcza lub mieszkalna użytkowana przez właścicieli zgodnie cyklem produkcji rolnej.

${ }^{26}$ Gamonal to pochodzące z XIX w. określenie właściciela ziemskiego, którego rodzina - z racji rozmiarów posiadłości oraz kontroli nad zatrudnionymi w nich chłopami - pełniła rolę lokalnego centrum władzy. Ponieważ do czasu wybuchu konfliktu wewnętrznego w $1980 \mathrm{r}$. zjawisko gamonalizmu niemal zanikło (jego upadek rozpoczął się już w latach 30. XX w., a w latach 70. ostatecznie rozbiła je reforma rolna), Świetlisty Szlak uznał za „wrogów ludu” nowych gamonali, czyli najbardziej zamożnych, często uwłaszczonych w wyniku reformy chłopów.

27 Zgodnie z relacją mojego rozmówcy, to pochodzący z Huancaveliki „Centurión” przekonał do udziału w inwazji wielu mieszkańców tego departamentu, w tym przede wszystkim jego nadgranicznej prowincji Angaraes. Jeśli chodzi o departament Ayacucho, reprezentowali go uciekinierzy z prowincji najbardziej dotkniętych terrorem, czyli północno-wschodnich oraz centralnych części regionu. W momencie organizacji akcji zasiedleńczej większość z jej przyszłych uczestników przebywała już jednak w mieście Ayacucho, dokąd dotarła po nieudanych próbach powrotu w Andy w latach 90. W mieście żyli $\mathrm{w}$ rozproszeniu, dlatego skuszono ich obietnicą posiadania parceli we wspólnym miejscu zamieszkania. Jak wyjaśnił mój rozmówca: „Mieli ją dostać w zamian za szkody wyrządzone przez państwo - bo to było główne hasło: odszkodowanie dla ronderos i ich rodzin" - rozmowa z Julianem Llancce, dom rodzinny w „Yanamie”, Ayacucho, 15 czerwca $2016 \mathrm{r}$.

${ }^{28} \mathrm{Na}$ podstawie rozmów z ajakuczańskim antropologiem i pracownikiem biura Komisarza ds. Pokoju i Rozwoju, Carlosem Condorim Castillo (biuro Komisarza, Ayacucho, 20 stycznia 2010 r.); reprezentantką rodziny Quispe Cordoba, Ildą Mariną oraz jej krewnym ze strefy Putis, Hectorem Fernandezem Quispe (dom rodzinny Ildy Quispe w dzielnicy Pokras, Ayacucho, 11 stycznia 2010 r.). 
W ramach strategii zasiedleńczej powołano Stowarzyszenie Komitetów Samoobrony Ayacucho i Huancaveliki ${ }^{29}$, które legitymizowało przywództwo CAD’s nad inicjatywą i jednocześnie stwarzało możliwość pozyskania ziem od państwa na specjalnych warunkach. Działania - którym oficjalnie przyświecał wspomniany już wcześniej, powszechny cel retornantes w postaci dostępu do rynku pracy, ochrony zdrowia i edukacji - podjęto jednocześnie pod pretekstem zadośćuczynienia za udział i poświęcenie członków CAD’s oraz ich rodzin $w$ walkach $z$ senderyzmem ${ }^{30}$. Warto zaznaczyć, iż sam proces poszukiwania ziem pod zasiedlenie zawierał początkowo elementy dialogu z władzami departamentu i, co szczególnie ważne, był wspierany przez wielu aktorów społecznych współpracujących ówcześnie z „samoobroną”, tj. nadzorujących jej aktywność wojskowych, wspierające ją organizacje pozarządowe, ale też lokalnych i regionalnych polityków, znających wagę poparcia członków sił chłopskich i ich rodzin jako elektoratu.

Koszty oferowanych uchodźcom terenów przewyższały jednak ich możliwości finansowe. Wówczas obiektem zainteresowania grupy stał się liczący około 30 ha fragment dawnej hacjendy Yanama. Zgodnie z relacją lidera akcji zasiedleńczej ziemie te były nieużytkami i miały zostać nabyte od ich właściciela za niewielką opłatą. W świetle jego słów decyzję o zbrojnej inwazji podjęto stosunkowo spontanicznie, gdy dzięki wizycie w urzędzie w Limie udało się ustalić, że spadkobierca z rodziny Quispe utracił prawa własności tych terenów ${ }^{31}$. Powszechnie uważa się jednak, że poszukiwanie przez afectados ziem o nieuregulowanym statusie prawnym było intencjonalne i miało charakter taktyczny, gdyż zbrojne zajęcie podobnych terenów otwierało

29 Hiszp. Asociación de los Comités de Autodefensa de Ayacucho i Huancavelica.

30 Stąd jedyne koszty zasiedlenia, jakie mieli ponieść członkowie-założyciele stowarzyszenia, to 20 soli w formie tzw. wpisowego (stanowiącego deklarację udziału danej rodziny w zasiedleniu) i następnie 450 soli jako opłata za przydzieloną parcelę (1 sol posiada wartość zbliżoną do 1 złotego); na podstawie rozmowy z Hectorem Fernandezem (biuro Komisarza ds. Pokoju i Rozwoju, Ayacucho, 7 stycznia 2010 r.).

31 Sam „Centurión” przedstawił mi genezę akcji zasiedleńczej w następujący sposób: „Były to tereny dawnej hacjendy, które dawno temu przekazano wspólnocie, a potem zostały podzielone między rodzeństwo Quispe. Właściciele zgodzili się sprzedać je za 3 sole za metr kwadratowy. Urządziliśmy wówczas wielka fiestę z pachamanką. Ja miałem znajomości w Ministerstwie Rolnictwa, więc pojechałem do Limy sprawdzić, czy ta rodzina na pewno miała tytuł własności tych ziem. Okazało się, że nabyli te tereny w formie nadania, która jest tymczasowa i w tym okresie już wygasła. Kiedy wróciłem do Ayacucho zażądałem, by przedstawili mi dokument własności oraz potwierdzenie o niezaleganiu z opłatami. Powiedziałem im potem, że nie zapłacę ani 15, ani 10, ani 3 sole, bo ziemie nie należą do nich tylko do państwa więc będę rozmawiał jedynie $\mathrm{z}$ władzami państwowymi” (rozmowa z „Centuriónem”, więzienie Yanamilla, Ayacucho, 9 stycznia 2010 r.). 
możliwość ich formalnego nabycia drogą ugody między stronami konfliktu w sądzie. Co więcej, wbrew słowom mojego rozmówcy, zajęte ziemie nie były nieużytkami, lecz obejmowały zarówno pola uprawne, jak i elementy zbudowanej przez rodzinę Quispe infrastruktury (o czym szerzej dalej).

Jak wynika $\mathrm{z}$ relacji świadków, inwazja miała nie tylko masowy, ale także brutalny przebieg. Rozpoczęła się 10 marca 2006 r., gdy w granicach dawnej hacjendy Yanama pojawiło się kilkudziesięciu przedstawicieli Stowarzyszenia, w tym głównie uzbrojeni liderzy CAD’s (często byli żołnierze) i ich krew$\mathrm{ni}^{32}$. Pod groźbą użycia broni zajęli interesujące ich tereny pampy, na których znajdowały się zabudowania należące do rodziny Quispe, jak również dojrzewały już wówczas uprawy. Miesiąc później do pierwszych osadników dołączyło kolejnych kilkanaście tysięcy osób, co uczczono wielodniową fiestą, ustanawiając 10 marca, czyli dzień początku inwazji, lokalnym świętem „Yanamy” (na wzór świąt fundacyjnych obchodzonych w rocznicę założenia miejscowości lub też oficjalnego powrotu do niej po wojnie). Odpowiedzialna za inwazję organizacja CAD's została przemianowana na Stowarzyszenie Mieszkańców „Miasta Aniołów Pokoju - Yanama”33, co zapewniło jej członkom quasi-formalny status nabywców zasiedlonych terenów, wskazując jednocześnie ich nowego administratora.

W trakcie akcji zasiedleńczej istniejąca infrastruktura i część zbiorów zostało zniszczonych. Choć poszkodowanej w wyniku inwazji rodzinie Quispe obiecano podjęcie negocjacji i, na ich podstawie, wykup zajętych ziem, jednocześnie zarówno właściciele terenu, jak i zainteresowani zdarzeniem dziennikarze byli zastraszani przy użyciu broni lub wręcz fizycznie atakowani przez uczestników akcji ${ }^{34}$. W tym samym czasie liczący około trzydzieści hektarów obszar inwazji

32 O brutalnym przebiegu akcji zasiedleńczej mówi się w Ayacucho zupełnie powszechnie. Sam moment inwazji w następujący sposób przedstawiła mi wspomniana już współwłaścicielka Yanamy, Ilda Quispe: „[...] najbardziej ucierpiała moja kuzynka, Rosa Quispe. Tej to nawet dom zburzyli. Boże! Jak ona wtedy płakała, aż żal człowieka zabijał. Wszyscy tam wtedy poszliśmy i wszyscy ją wpieraliśmy w tym płaczu [hiszp. todos le hemos ayudado a llorar...] Ja tam do dziś się boję iść, bo Centurión krzyczał, że tyle ludzi już zabił, że nie ma strachu by dalej zabijać”. Ta sama rozmówczyni przekazała mi, że w momencie zasiedlenia na terenie hacjendy uprawiano zboża i kukurydzę, których żniwa przypadają w maju i czerwcu. Oznacza to, że dla właścicieli Yanamy inwazja wiązała się nie tylko z grabieżą gruntów, ale również bezpośrednią szkodą finansową (rozmowa w domu rodzinnym Ildy Quispe w dzielnicy Pokras, Ayacucho, 11 stycznia 2010 r.).

33 „Czynnik CAD’s” pozostał jednak ważnym elementem wizerunku osiedla, bo zachowano go w jego pełnej nazwie, która brzmi: Asociación de Viviendas „Ciudad los Angeles de la Paz-Yanama” de los Comités de Autodefensa de Ayacucho i Huancavelica [przyp. J.P.-S.].

34 Przypadków zastraszeń było wiele i polegały najczęściej na grożeniu bronią osobom kwestionującym zasadność zasiedlenia. Najbardziej brutalnym aktem przemocy okazała 
podzielono na równe działki wielkości $200 \mathrm{~m}^{2}$, na których miały stanąć domy blisko dwudziestu tysięcy jej beneficjentów. Ponieważ jednak wiele rodzin wycofało się z deklarowanego wcześniej udziału w zasiedleniu, przeznaczone dla nich parcele stały się przedmiotem handlu ziemią, w wyniku czego trafiały w ręce nabywców niezwiązanych z pierwotną ideą akcji. Podobna praktyka przyczyniła się do jeszcze silniejszego różnicowania i kategoryzacji mieszkańców, które zachodziły nie tylko pod kątem ich pochodzenia, ale też form użytkowania parceli. Coraz większa liczba afectados zaczynała bowiem korzystać z tych gruntów jako kolejnej własności w ramach stale rosnącej „puli” posiadanych miejsc zamieszkania. Jako teren podmiejski parcele „Yanamy” uważane były bowiem za korzystną lokatę kapitału i, tym samym, bardzo szybko zyskiwały na wartości (w zależności od położenia ich koszt wahał się od trzech do ośmiu tysięcy soli). Niemniej, ponieważ za ich komercjalizację odpowiadały władze Stowarzyszenia, proceder ten nie tylko nasilił krytykę opinii publicznej wobec sposobu przeprowadzenia akcji zasiedleńczej, ale również poważnie naruszył wiarygodność jej pierwotnego celu, jakim miało być zadośćuczynienie ofiarom politycznego terroru i wywołanych przezeń przesiedleń. Kulminacją kontrowersji wokół „Yanamy” stało się aresztowanie i postawienie w stan oskarżenia jej lidera, Estebana „Centurióna” Quispe. Choć jako przywódca sił chłopskich był już wówczas poszukiwany za szereg wykroczeń z czasów wojny, wraz z przeprowadzeniem inwazji stał się również symbolem negatywnych cech procesów zasiedleńczych, w tym przede wszystkim brutalności invasores wobec innych cywilów, uważanej przez opinię publiczną za kontynuację paramilitarnej aktywności CAD’s z okresu walki z senderyzmem ${ }^{35}$.

W tym samym czasie, mimo trwających batalii sądowych $\mathrm{z}$ właścicielami gruntu, jak również kolejnych procesów karnych „Centurióna”, wyraźnie postępowała reorganizacja terenów inwazji jako podmiejskiego osiedla Ayacucho. Życie mieszkańców toczyło się w obrębie sektorów, których administrację powierzono wspólnotom chłopskim reprezentującym różne re-

się jednak napaść na dziennikarza Radia Atlantis, Waltera Yaraskę Quispe. W październiku 2006 r. został on zaatakowany w Ayacucho przez grupę kobiet, które, mszcząc się za jego dochodzenia medialne nt. „Yanamy”, pobiły go i okaleczyły (informację uzyskałam po raz pierwszy w styczniu 2010 r. od Ildy Quispe, niemniej potwierdzają ją również źródła internetowe; zob. m.in. Desconocidas golpean y cortan a periodista radial, https:// ifex.org/es/desconocidas-golpean-y-cortan-a-periodista-radial (dostęp: 3.09.2021).

35 Na podstawie rozmów z huanteńskim badaczem i aktywistą, José Coronelem (Ayacucho, siedziba UNICEF, 30 stycznia 2009 r.); Carlosem Condorim Castillo (biuro Komisarza, Ayacucho, 20 stycznia 2010 r.); liderem inwazji, „Centuriónem” (więzienie Yanamilla, Ayacucho, 9 stycznia 2010 r.) oraz członkiem władz osiedla, Julianem Llancce (dom rodzinny w „Yanamie”, Ayacucho, 15 czerwca 2016 r.). 
giony pochodzenia afectados. Było to typowe dla powojennych praktyk tych ostatnich, bo stwarzało warunki do uczestnictwa w przywilejach dużej społeczności, nie wykluczając przy tym zachowania odrębności własnej grupy kulturowej wyznaczonej przez granice wyznań i tradycji wspólnotowych. Centralnym wydarzeniem w życiu społecznym „Yanamy” (na które od początku inwazji kładli nacisk jej liderzy) pozostały jednak obchody rocznicy zasiedlenia, czyli fiesta de 10 de marzo. Co istotne, służyły one nie tylko integracji różniących się pod względem kulturowo-religijnym społeczności chłopskich, które - poprzez zaproszenie do prezentacji folkloru i praktyk kulinarnych oraz udział we wspólnej defiladzie i rywalizacjach sportowych - jednoczono wokó „Yanamy” jako symbolu siły ofiar konfliktu ${ }^{36}$. Organizowane oficjalnie rocznice zasiedlenia stosunkowo szybko stały się również - przynajmniej manifestacyjnie - przestrzenią społecznej i politycznej inkluzji mieszkańców osiedla. Huczne obchody święta, w których początkowo brały udział przede wszystkim zainteresowane wsparciem afectados podmioty pozarządowe (i ewentualnie pojedynczy urzędnicy), w ciągu kilku lat stały się bowiem niemal obowiązkowym celem wizyt regionalnych polityków. Tak oto wiosenna i znana z ludycznego charakteru fiesta 10 marca "udzieliła" przestrzeni wiecom politycznym dedykowanym w sposób taktyczny stale rosnącej i jednocześnie podatnej na populistyczne obietnice grupie elektorów ${ }^{37}$.

W ciągu kilku lat status prawny ziem „Yanamy” został rozstrzygnięty w sądzie, który przyznał poszkodowanym członkom rodziny Quispe symboliczne odszkodowanie od invasores ${ }^{38}$. W tym samym czasie, korzystając z zainteresowania ze strony regionalnych polityków, władze osiedla pozyskały dla jego mieszkańców podstawowe inwestycje państwa w infrastrukturę (wytyczenie i utwardzenie dróg, elektryczność i obiekty dla szkół podstawowych). Niemniej, uregulowanie tytułów własności oraz rozwiązanie najważniejszych wyzwań infrastrukturalnych nie było jednoznaczne $\mathrm{z}$ rozpoczęciem regularnej rozbudowy i modernizacji „Yanamy”. Tak z powodów obiektywnych (położenie na zboczu wzgórza, brak własnych ujęć wody), jak i subiektywnych (kontrowersje

36 Co wymaga podkreślenia, od początku inwazji ważna była świeckość fiesty. Ponieważ część ludności prowincji przyjęła w okresie wojny wyznania ewangelickie, wybór katolickiego patrona święta (który był praktykowany od czasów kolonialnych) utrudniałby uczestnictwo wszystkich mieszkańców w obchodach rocznicy; na podstawie rozmowy z „Centuriónem”, więzienie Yanamilla, Ayacucho, 13 stycznia 2010.

37 Podczas mojej ostatniej wizyty w „Yanamie” w połowie 2016 r. osiedle liczyło ponad 12000 mieszkańców [przyp. J.P.-S.].

38 W zależności od jakości ziem było to od 1 do 5 soli za $\mathrm{m}^{2}$; na podstawie rozmowy z Ildą Quispe i Hectorem Fernandezem, dom rodzinny w dzielnicy Pokras, Ayacucho, 11 stycznia $2010 \mathrm{r}$. 
wokół okoliczności powstania osiedla, niejasne reguły handlu ziemią, jak również wysokie ceny parceli) pozyskanie środków na dalsze inwestycje okazywało się coraz trudniejsze. W efekcie, mieszkańcy zostali skonfrontowani z problemami, przed którymi uciekli tuż po wojnie $\mathrm{z}$ terenów wiejskich: złymi warunkami sanitarnymi, deficytem wody czy utrudnieniami transportowymi (które były jednoznaczne z ograniczeniem dostępu do pracy i szkoły w Ayacucho). Jak można wnioskować, osłabiło to zainteresowanie „Yanamą” ze strony nowych nabywców, a przed tymi, którzy ją współtworzyli, postawiło wyzwanie poszukiwania lepszych warunków zamieszkania. W ten sposób powrócił (!) fenomen retorno. Co ciekawe, rozczarowanie standardem życia pod Ayacucho dotknęło najbardziej pierwszych mieszkańców osiedla. Dysponując środkami pozyskanymi dzięki pracy w stolicy departamentu, część z nich szukała możliwości migracji do miasta lub też, nierzadko, decydowała się na reemigrację w rodzinne strony, gdzie rozbudowywała chacrę i wracała do pracy na roli. Ponieważ od czasu zakończenia konfliktu w wielu regionach środkowo-południowej prowincji pojawiły się inwestycje państwa w transport, infrastrukturę i szkolnictwo, w modernizowanych po wojnie, nowych ośrodkach administracyjnych terenów wiejskich ${ }^{39}$ retornantes odnajdowali często lepsze warunki pracy, edukacji czy handlu niż w prowizorycznych i pozbawionych wody osiedlach podmiejskich, jak „Yanama”. Te ostatnie pozostały inwestycją w ziemię i, ewentualnie, miejscem rodzinnych spotkań w okresie zimy (tj. andyjskiej pory deszczowej $)^{40}$.

\section{Zamiast zakończenia}

W roku 2015 trafiłam po raz pierwszy do strefy Putis na wyżu Huanty, do której zaprzyjaźnione rodziny afectados obiecywały zabrać mnie od lat ${ }^{41}$. Poszukując tematu do dalszych badań, wiodłam z nimi spokojne życie, kon-

39 Są to tzw. centros poblados, czyli stosunkowo duże, bo liczące nawet kilka tysięcy mieszkańców wsie (odpowiednik naszych gmin), które „rosły” już w czasie wojny w wyniku napływu uciekinierów ze zniszczonych stref (przez co wojsko często tworzyło w nich wspomniane już bazy antywywrotowe). Po zakończeniu konfliktu stały się nowymi centrami życia publicznego, handlu oraz edukacji na prowincji (i, jednocześnie, sposobem władz centralnych na depopulację miast).

40 Na podstawie rozmów z José Coronelem (Ayacucho, siedziba UNICEF, 30 stycznia 2009 r.), Julianem Llancce (dom rodzinny rozmówcy, „Yanama”, Ayacucho, 15 czerwca 2016 r.) oraz imigrantką z Chungui i mieszkanką „Yanamy”, Soraidą (urząd miejski w Carmen Alto, Ayacucho, 15 czerwca 2016 r.); zob. też Yanama celebra aniversario en medio de carencias, „Correo” 12.03.2017.

41 Strefa Putis to rubieże nie tylko departamentu Ayacucho, ale też obszarów górskich, które przechodzą w jej wschodniej części w tzw. selwę wysoką. W jej regionie przez 
centrując uwagę na procesach ich readaptacji do życia w Andach i, niełatwych do zrozumienia dla osoby z zewnątrz, mechanizmach pojednania. Im dłużej przebywałam wśród reemigrantów, tym trudniej było mi jednak dostrzec model ich zachowań migracyjnych i postawić granicę między praktykami, w ramach których miał miejsce powrót, oraz tymi, które oznaczały ucieczkę. W goszczącej mnie rodzinie młoda gospodyni odbierała okolicę jako oazę spokoju i nazywała ją „domem”. Twierdziła tak, mimo iż strefa Putis była miejscem pochodzenia jej męża, którego poznała w mieście Ayacucho i z którym rozpoczęła zupełnie nowe życie w Andach dopiero wiele lat po wojnie. Sama pochodziła ze znacznie niżej położonych i bardziej zaludnionych okolic stolicy departamentu, do której przeniosła się wraz z rodziną pod koniec lat 80 . z powodu terroru, doświadczając do momentu naszego spotkania kilkunastu (!) epizodów ucieczek i powrotów. Na jej powojenny „dom” na wyżu Huanty składały się nie tylko obiekty mieszkalne, ale także rozległa chacra jako przestrzeń upraw warzyw i hodowli zwierząt, jak również górskie trasy w kierunku szkoły, sklepu czy też domostw sąsiadów, które jej najmłodsze dzieci mogły pokonywać samodzielnie bez obaw o bezpieczeństwo. Jej mąż, urodzony na wyżu comunero (członek wspólnoty), również nie posiadał z Putis wielu wspomnień, choć jego przodkowie mieszkali tam od pokoleń, a w latach 30 . XX w. zakupili sporą część lokalnej hacjendy. On jednak spędził ostatnie dekady w szeregach kolejnych formacji zbrojnych - wcielony jako nastolatek do sił Świetlistego Szlaku, w latach 90. trafił do więzienia, by następnie pracować dla wojska w charakterze przewodnika i wkrótce stać się liderem chłopskiej samoobrony. Co ciekawe, $\mathrm{z}$ całej goszczącej mnie rodziny to on czuł się na wyżu najbardziej, nomen omen, nieswojo, twierdząc, że nigdy „nie był chłopem”, a jego „miejsce jest w mieście”. Należy się domyślać, że podobna zmiana tożsamości była następstwem doświadczeń wojennych. To także w ich wyniku w Ayacucho czekał na niego murowany dom i uczące się, dorastające córki, jak również obowiązki zawodowe i wyzwania polityczne.

wiele lat trwały walki wojska ze Świetlistym Szlakiem, którego jednostki nadal zajmują się na tych terenach narkohandlem. $Z$ tego powodu akt oficjalnego powrotu putisanos w rodzinne strony miał miejsce dopiero 2008 r., ale nawet wówczas był na tyle ryzykowany, że przez wiele następnych lat miejscowe rodziny obawiały się zabrać mnie na wyż (również przez wzgląd na własne bezpieczeństwo). Gdy w 2015 r. wznowiłam badania w Andach, sytuacja w Putis była już stosunkowo stabilna. Obecnie na strefę składa się 10 wspólnot chłopskich ze stolicą w centro poblado Rodeo. Niemal wszyscy ich mieszkańcy są migrantami powrotnymi (lub ich małżonkami i dziećmi; $\mathrm{z}$ powodu wielostronnego terroru strefa wyludniła się w okresie wojny). 
Stąd też, gdy twierdził, że „wraca” do miasta, wydawało się, że chce powiedzieć, że „ucieka ze wsi”" ${ }^{42}$.

Jeśli przyjrzeć się przedstawionym $\mathrm{w}$ tekście realiom życia andyjskich retornantes, łatwo dostrzec, że jak w soczewce skupiają w sobie źródła złożoności współczesnych procesów migracyjnych. Stanowią jednocześnie przykład per excellence amorficzności „powrotów” analizowanej w polskich badaniach nad migracjami między innymi przez Krystynę Romaniszyn i Dariusza Niedźwiedzkiego. Jako zjawisko społeczne charakteryzują się bowiem tak niewielką skalą powtarzalności, że trudno zmieścić je w klasycznych modelach migracyjnych jak reemigracja (bo są bardzo dynamiczne i rzadko oznaczają powrót na stałe) czy migracja wahadłowa (bo wiążą się najczęściej z cyrkulacją między wieloma miejscami pobytu, których wybór wynika $\mathrm{z}$ różnych motywacji ${ }^{43}$. Co więcej, jak wykazałam w tekście, andyjskie powroty odbywają się $\mathrm{w}$ ramach zupełnie nowej geografii mobilności przestrzennej afectados. W odniesieniu do tez E. Nowickiej i D. Niedźwiedzkiego oznacza to, że nie tyle biegną wzdłuż określonych tras, co raczej rozwijają się w stale rosnącej przestrzeni zachowań migracyjnych ${ }^{44}$. W ten sposób współtworzą zjawisko taktycznej cyrkulacji migrantów, odbywającej się nie tylko między wieloma miejscami zamieszkania, ale też $\mathrm{w}$ obrębie różnych sieci interakcji, w których badani przeze mnie afectados posiadają odmienne statusy i tożsamości. Analizowany przypadek jest w tym zakresie szczególny przez wzgląd na zarysowane w tekście, historyczno-kulturowe modele migracji w Środkowych Andach, w tym przede wszystkim tradycję „archipelagów pionowych”, czyli eksploatację przez społeczności regionu różnych stref ekologicznych. Jeśli przyjrzeć się współczesnym cyrkulacjom afectados, wydają się nie tyle podtrzymywać, co wręcz rozbudowywać skalę tej praktyki, wzbogacając ją o - pozyskane w czasie wojny - niewielkie parcele w mieście (i niekiedy również selwie). Większość rodzin chłopskich z terenów środ-

42 Na podstawie badań wśród putisanos w czasie ich przesiedlenia w Ayacucho (listopad 2007 r., styczeń 2009 r., styczeń 2010 r.) oraz powrotu do Putis (październik 2015 r., czerwiec 2016 r.). Nasz wspólny pobyt w Putis opisałam w tekście w czasie przeszłym, bo podobne doświadczenie raczej się nie powtórzy. Z powodu pogróżek ze strony Świetlistego Szlaku część mieszkańców wraz z najmłodszymi dziećmi u ci e kło z wyżu. Ich nowego miejsca zamieszkania - na moje własne życzenie - nie znam dokładnie.

43 K. Romaniszyn, op. cit., s. 32-35; D. Niedźwiedzki, op. cit., s. 29-44; zob. również E. Nowicka, op. cit. oraz G. Babiński, op. cit. Z tych samych powodów, zgodnie z ujęciem K. Romaniszyn, nie są „definicyjnymi” powrotami, przez co należałoby określać je bardziej precyzyjnie jako „quasi-powroty” lub, w wielu przypadkach, „przymusowe powroty”; K. Romaniszyn, op. cit., s. 34.

44 E. Nowicka, op. cit., s. 11-14; D. Niedźwiedzki, op. cit., s. 31-32. 
kowo-południowej prowincji posiada bowiem współcześnie usytuowane na różnych wysokościach chacras (w których mieszkają głównie ludzie starsi oraz matki z najmłodszymi dziećmi i w których produkuje się żywność do własnej konsumpcji) oraz domy w ośrodkach miejskich (w których przebywają pracujący ojcowie oraz uczące się lub studiujące dzieci i w których cała rodzina spędza nierzadko zimę $\left.{ }^{45}\right)$. Warto podkreślić, że miejskie „ogniwo” tras cyrkulacji ludności andyjskiej nie istniało najczęściej przed okresem konfliktu. Wszystko to sprawia, że praktyki migracyjne i wzory zamieszkiwania są w jej przypadku w widocznym stopniu zindywidualizowane (choć, jak sama wskazuję w tekście, posiadają też pewne cechy wspólne). Oznacza to, że - zgodnie $\mathrm{z}$ dominującymi w studiach nad mobilnością przestrzenną tendencjami - badanie powojennych powrotów w Andy wymaga podejścia interdyscyplinarnego, z uwzględnieniem zarówno dorobku „klasycznej” socjologii migracji, jak również antropologii domu, studiów nad tożsamością i swojskością/obcością, jak również fenomenem transkulturowości czy też psychologii migracji oraz elementów ekonomii.

W odniesieniu do analizowanego przeze mnie przypadku powyższa uwaga metodologiczna mnoży wyzwania. Kazus akcji zasiedleńczych retornantes wymaga bowiem zestawienia ze sobą zagadnień niezwykle obszernych: historii regionu, studiów nad konfliktem wewnętrznym, jak również tzw. problemu ziemi. W tym miejscu warto przyjrzeć się temu ostatniemu. Jak już sygnalizowałam, w powiązaniu $\mathrm{z}$ inwazjami na tereny byłych hacjend oznacza on eskalację lokalnych konfliktów społecznych na różnych osiach. Poza tą oczywistą, jaką jest konfrontacja invasores - właściciele gruntów (czyli, w ujęciu historycznym, chłopi - ziemianie), prowadzi również do nasilenia antagonizmu chłopi - państwo (jako wyniku „zmęczenia” tych pierwszych dysfunkcyjnością państwa na prowincji tak przed, w trakcie, jak i po konflikcie), ale też chłopi - chłopi (przez wzgląd na fakt, iż reforma rolna i wojna domowa wyraźnie zróżnicowały ludność chłopską pod kątem statusu społeczno-ekonomicznego). Co warte uwagi, dla badacza spoza andyjskiej ekumeny analiza każdego $\mathrm{z}$ nich stanowi wyzwanie metodologiczne, w tym przede wszystkim w zakresie posługiwania się perspektywą emic. Wymaga ona bowiem dostrzeżenia i zrozumienia specyficznego porządku logicznego, leżącego u źródeł akcji zasiedleńczych, zgodnie z którym nieuregulowany status prawny zajmowanych ziem i przedłużające się procesy sądowe, dotyczące ich własności stanowią dla uczestników inwazji korzyść. Stąd też ich liderzy intencjonalnie poszukują terenów o niejasnym statusie prawnym, dzięki czemu

45 Czyli wakacje, bo wypadają one w andyjskiej porze deszczowej, tj. między grudniem i marcem. 
mogą prowadzić akcje zasiedlenia i, następnie, budować przez lata infrastrukturę osiedla, mając pewność, że ani państwo, ani też domniemani właściciele gruntów nie podejmą próby ich przejęcia bez rozstrzygnięć sądowych ${ }^{46}$. Kluczowym elementem ich strategii jest również zbiorowy charakter akcji, który sprawia, że prawdopodobieństwo eksmisji nowych mieszkańców, czyli de facto siłowego przejęcia ziem przez innego aktora, znacząco maleje, zwiększając tym samym szanse invasores na polubowne rozwiązanie sporu przez sąd. Warto pamiętać, iż opisany mechanizm jest stosunkowo powszechny nie tylko w Peru, ale również innych państwach regionu, a w jego wyniku - wraz $\mathrm{z}$ masowym napływem uciekinierów wojennych - powstają kolejne dzielnice zarówno prowincjonalnych miast, jak i najważniejszych w kraju metropolii. Masowość procesu wynika jednak nie tylko ze skali przemocy politycznej, która powoduje ucieczki cywilów ze wsi do ośrodków miejskich, ale także swoistego przyzwolenia tak ze strony władz, jak i nierzadko opinii publicznej na akcje zasiedleńcze afectados. By zatem nie popełnić błędu eurocenryzmu i nie postrzegać zjawiska jedynie przez pryzmat jego kryminogennego rysu, należy spojrzeć na nie z perspektywy oddolnej, uwzględniającej między innymi jego historyczne uwarunkowania. Jeśli przyjrzeć się bowiem badaniom latynoamerykańskim, w ich świetle problem wydaje się bardziej neutralny. Zbiorowe zasiedlenia powszechnie traktowane są jako inwersja porządków kolonialnych, w ramach których tzw. presja na ziemię i wynikające z niej inwazje na tereny rolne odbywały się przez wieki kosztem ludności tubylczej. Współcześnie, drogą zorganizowanych akcji zasiedleńczych, ta ostatnia odbiera od państwa tzw. dług historyczny. Zasadność podobnych praktyk jest tym większa, jeśli problem dotyczy cywilów zaangażowanych w okresie konfliktu do działań zbrojnych, lecz przy tym nieobjętych należną im pomocą i odszkodowaniami. W ten sposób postawy mogące wydawać się zewnętrznemu obserwatorowi roszczeniowe w powojennych realiach prowincji stają się wyrazem aktywizacji - poszkodowanej w wyniku przemocy politycznej

46 W podobną argumentację ciężko było mi uwierzyć na podstawie pierwszych rozmów na temat „Yanamy”, bo - z racji trudnych warunków bytowych, jakie w niej panują - wynik inwazji może wydawać się zewnętrznemu obserwatorowi przejawem porażki afectados. Dokładnie to samo ustaliłam jednak w Aykas pod Huantą. Jest to rozległy, pięknie położony teren o formie płaskowyżu, w przypadku którego w procesie parcelacji gruntów doszło najprawdopodobniej do oszustwa ze strony pośrednika sprzedaży. W efekcie, Aykas jest od wielu lat zasiedlane przez migrantów z różnych części regionu i stopniowo (ale wyłącznie oddolnie) rozwijane, bo - jak mi powiedziano - „tematu własności nikt nigdy nie rozstrzygnie, więc siłą nikogo nie wygonią”; spotkanie z władzami osiedla (Aykas, Huanta, 7 października 2016 r.) oraz rozmowa z prezydentem CAD’s Putis, Dario (droga z Putis do Huanty, 7 października 2016 r.). 
- ludności andyjskiej ${ }^{47}$. Oddolną perspektywę problemu oddają słowa jednego z mieszkańców „Yanamy”. W odpowiedzi na pytanie, „czy wszyscy invasores są w jakimś stopniu migrantami powrotnymi”, mój rozmówca wyjaśnił: „Tak, [w Andach - przyp. J.P.-S.] wracają do swojej tożsamości, na swoją ziemię. Ale większość nie jest już w stanie oswoić się ponownie z tymi warunkami: zimnem, brakiem transportu, dróg, dostępu do pracy i szkoły. Idą więc w kierunku miast, by nie żyć nadal w warunkach dysfunkcji państwa na prowincji. To wszystko dla nas szansa na rozwój” ${ }^{48}$.

$\mathrm{Na}$ koniec rozważań należy przypomnieć, iż analizowany przypadek akcji zasiedleńczej jest o tyle specyficzny, że jego „klasycznym” cechom jak masowość czy wojenna geneza towarzyszyło - dodatkowo - uczestnictwo i użycie siły ze strony uzbrojonych chłopów (w tym również byłych żołnierzy, bo część z nich odbyła wcześniej służbę wojskową). Problem ten skłania do refleksji nad współczesnymi rolami cywilnych komitetów samoobrony, na co w tym tekście nie ma jednak $\mathrm{w}$ rozbudowanej formie miejsca ${ }^{49}$. Ulokowanie ich problematyki w węższym kontekście przebiegu powrotów w Andy i powiązanych z nimi inwazji pozwala natomiast zauważyć, że wojenne porządki społeczne, jakie powołały i narzuciły mieszkańcom prowincji siły samoobrony (a których modele teoretyczne zaproponowała m.in. A. Arjona), znalazły swoją kontynuację po wojnie (co zainteresowało m.in. M. Fumertona oraz C. Tapię) ${ }^{50}$. Poza ich oczywistym, przemocowym wymiarem, uwagę zwraca również ten konstruktywny, który tak w okresie konfliktu, jak i po jego zakończeniu zdaje się stanowić następstwo słabej obecności instytucji państwowych na prowincji. Podczas gdy problem ten był szeroko badany w odniesieniu do czasu wojny (w ujęciu krytycznym wobec państwa zrobił to m.in. C. I. Degregori, J. Coronel, P. del Pino, O. Starn czy wskazany tu M. Fumerton $)^{51}$, w okresie powojennym wyraźnie

47 Zob. koniecznie: C. Blondet, C. I. Degregori, N. Lynch (red.), IEP, Conquistadores de un nuevo mundo. De invasores a ciudadanos en San Martin de Porres. Obras escogidas VIII, Lima 2014; jak również F. J. Lozano Martínez, op. cit.

48 Wypowiedź Juliana Llancce, dom rodzinny w „Yanamie”, Ayacucho, 15 czerwca 2016 r.

49 Temat ten podjęłam tuż po wojnie i został ujęty w tekście z 2008 r., niemniej zdecydowanie wymaga aktualizacji. Od kilku lat aktywność CAD’s spada bowiem na wszystkich jej poziomach, co prawdopodobnie oznacza także jej ewolucję (w tym również w kierunkach kryminogennych); zob. J. Pietraszczyk, op. cit. oraz M. Fumerton, Beyond Counterinsurgency..., s. 69-80.

50 A. Arjona, op. cit. oraz M. Fumerton, Beyond Counterinsurgency..., s. 69-80 i C. Tapia, Las Rondas Campesinas, los CAD's y la Policía Rural, [w:] Comisionado para la Paz y Desarrollo (red.), Cultura de Paz, Seguridad Ciudadana y Comités de Autodefensa, Ayacucho 2004.

51 Zob. przede wszystkim pracę zbiorową pod redakcją C. I. Degregoriego, Las rondas campesinas..., oraz M. Fumerton, Las rondas campesinas..., s. 470-497. 
stracił na popularności. Pozwoliło to krytykom fenomenu CAD’s zredukować jego zewnętrzną percepcję do wymiaru militarnego i, w ten sposób, wzmocnić postulat pełnej demobilizacji „samoobrony” jako źródła zagrożeń dla pokoju. Nie ulega jednak wątpliwości, że po zakończeniu działań zbrojnych siły chłopskie były przez lata głównym aktorem strzegącym oddolnie interesów afectados/retornantes, a na ich regularną aktywność składało się nie tylko konwojowanie powrotów i zapewnienie bezpieczeństwa prowincji, ale też konsekwentne starania o programy pomocowe oraz ogromna aktywizacja społeczna i polityczna ludności chłopskiej. Jak wykazałam, jedną z form ich powojennej działalności było również inicjowanie tzw. inwazji, w wyniku których - mimo towarzyszących im kontrowersji etycznych i prawnych - powstały stosunkowo bezpieczne i służące andyjskim rodzinom w różnych okolicznościach „domy miejskie". Stąd też badanie akcji zasiedleńczych z udziałem sił chłopskich to, poza wieloma wyzwaniami merytorycznymi, przede wszystkim trening zmiany perspektyw wymagający stałego godzenia ze sobą dystansów poznawczych między retornantes, aktorami państwowymi oraz osobą badacza jako zewnętrznego obserwatora głęboko nieoczywistych w swojej istocie następstw wojny.

\section{Bibliografia}

Aguirre Cárdenas M., Ayacucho: Vilcashuaman y Cangallo. Gloria y ocaso de una heroica región andina, San Juan de Miraflores 2008.

Arjona A., Wartime Institutions: A Research Agenda, „Journal of Conflict Resolution" 2014, vol. 58, no. 8.

Asociación Pro Derechos Humanos, Los Desplazados. 600000 ciudadanos peruanos sin derechos, Lima 2000.

Babiński G., Return Migration Revisited, [w:] E. Nowicka, H. Firouzbakch (red.), Homecoming. An Anthropology of Return Migrations, Nomos, Kraków 2008.

Barrantes Segura R., Reparations and Displacement in Peru, International Center for Transitional Justice (ICTJ) 2012.

Benewith S., Olas de cambio: Violencia politica y desplazamiento durante la Guerra Interna en el Perú (1980-2000), Independent Study Project Collection 2017, 2733, https://digitalcollections.sit.edu/isp_collection/2733 (dostęp: 11.03.2019).

Blondet C., Degregori C. I., Lynch N. (red.), Conquistadores de un nuevo mundo. De invasores a ciudadanos en San Martin de Porres. Obras escogidas VIII, Lima 2014.

Buliński T., Czym jest antropologizcja nauk?, [w:] A. Pomieciński, S. Sikora (red.), Zanikające granice. Antropologizacja nauki i jej dyskursów, Poznań 2009. 
Cavero Carraso R., UNSCH „...imposible es morir”. Universidad satanizada, asfixiada y violentada, Huancayo 2005.

Comisión de la Verdad y Reconciliación, Hatun Willakuy. Versión abreviada del Informe Final de la CVR, Lima 2008.

Degregori C. I., El surgimiento de Sendero Luminoso. Ayacucho 1969-1979, Lima 2010.

Degregori C. I., Sendero Luminoso. I. Los hondos y mortales desencuentros, II Sendero Luminoso: lucha armada y utopía autoritaria, Documento de Trabajo n. 4 y 6, Lima 1985.

Degregori C. I. (red.), Las rondas campesinas y la derrota de Sendero Luminoso, Lima 1996.

Desconocidas golpean y cortan a periodista radial, https://ifex.org/es/desconocidas-golpean-y-cortan-a-periodista-radial/ (dostęp: 20.07.2021).

Fumerton M., Beyond Counterinsurgency: Peasant Militias and Wartime Social Order in Peru's Civil War, „European Review of Latin American and Caribbean Studies" 2018, no. 105, s. 61-86.

Fumerton M., Rondas Campesinas in the Peruvian Civil War: Peasant Self-Defence Organisations in Ayacucho, „Bulletin of Latin American Research” 2001, vol. 20, no. 4, s. 470-497.

Gorriti G., Sendero Luminoso. Historia de la guerra milenaria en el Perú. Tomo I, Lima 1990.

Jiménez E., Chungui. Violencia y trazos de memoria, Lima 2009.

Klarén P., Nación y sociedad en la historia del Perú, Lima 2004.

Lozano Martínez F. J., Desplazados por violencia en asentamientos humanos de Huanta y Lima. Perú, Guadalajara 2011.

Manrique N., El tiempo del miedo. La violencia política en el Perú 1980-1996, Lima 2002.

Mayer E., Cuentos feos de la reforma agraria peruana, Lima 2017.

Mesa nacional sobre desplazamiento, Balance del proceso de desplazamiento por violencia política en el Perú (1980-1997), „Amérique Latine Histoire et Mémoire. Les Cahiers ALHIM” 2002, nr 5; Web. 26 February 2019, http:// journals.openedition.org/alhim/647 (dostęp: 19.03.2019).

Murra J., El mundo andino. Población, medio ambiente y economía, Lima 2014.

Niedźwiedzki D., Migracje i tożsamość. Od teorii do analizy przypadku, Kraków 2010.

Nowicka E., Introduction. The Study of Return Migrations, [w:] E. Nowicka, H. Firouzbakch (red.), Homecoming. An Anthropology of Return Migrations, Kraków 2008, s. 9-20.

Nowicka E., Firouzbakch H., Homecoming. An Anthropology of Return Migrations, Kraków 2008. 
Ochatoma Paravicino J., Cabrera Romero M., Religión y militarismo en la antigua ciudad Wari, [w:] R. Ayala Huaytalla (red.), Entre la región y la nación. Nuevas aproximaciones a la histora ayacuchana y peruana, Lima 2013.

Pereyra Chávez N. E., Élite, poder y disciplina en el Perú temprano colonial: el caso de Huamanga, 1539-1550, [w:] R. Ayala Huaytalla (red.), Entre la región y la nación. Nuevas aproximaciones a la histora ayacuchana y peruana, Lima 2013.

Pietraszczyk J., Peruwiańskie Komitety Samoobrony - w poszukiwaniu nowej roli społecznej, [w:] M. Kania, A. Kaganiec-Kamieńska (red.), Doświadczenie demokracji w Ameryce Łacińskiej, Kraków 2008.

Pietraszczyk-Sękowska J., Peruwiańskie siły samoobrony chłopskiej. Od konfliktu zbrojnego do transformacji pokojowej, t. II, Poznań 2011 (maszynopis pracy doktorskiej).

Pietraszczyk-Sękowska J., Powroty po(do) bliskich. O paradoksach migracji powrotnych $i$ ich zwiazkach $z$ poszukiwaniami desaparecidos $w$ Andach peruwianskich końca XX i początku XXI wieku, „Ameryka Łacińska” 2020, nr 1, s. 15-38.

Posern-Zieliński A., Wspólne obszary refleksji: społeczno-kulturowej antropologii, nauk o polityce i nauk prawnych, [w:] A. Pomieciński, S. Sikora (red.), Zanikające granice. Antropologizacja nauki i jej dyskursów, Poznań 2009.

Rodriguez Vargas M., Espinosa de Rivero O. (red.), Multiples retornos a una misma tierra. La situación del pueblo Asháninka de los ríos Tambo y Ené - Selva Central, Lima 1997.

Roel Pineda V., Historia social y económica de la colonia, Lima 1999.

Romaniszyn K., Migration Networks and Return Migration, [w:] E. Nowicka, H. Firouzbakch (red.), Homecoming. An Anthropology of Return Migrations, Kraków 2008.

Salas Olivari M., La ciudad-región de Huamanga: de los tiempos prehispánicos a la era colonial y republicana inicial, [w:] R. Ayala Huaytalla (red.), Entre la región y la nación. Nuevas aproximaciones a la histora ayacuchana y peruana, Lima 2013.

Skoczek M., Zmiany mobilności przestrzennej ludności Ameryki Łacińskiej jako efekt globalizacji, [w:] M. F. Gawrycki (red.), Ameryka Łacińska wobec wyzwań globalizacji, Torun 2006.

Śniadecka-Kotarska M., Kobiety w migracjach przesiedleńczych w Peru (19802000), „Środkowoeuropejskie Studia Polityczne” 2006, nr 1, s. 47-62.

Tapia C., Las Fuerzas Armadas y Sendero Luminoso. Dos estrategias y un final, Lima 1997.

Tapia C., Las Rondas Campesinas, los CAD’s y la Policía Rural, [w:] Comisionado para la Paz y Desarrollo (red.), Cultura de Paz, Seguridad Ciudadana y Comités de Autodefensa, Ayacucho 2004. 
Tung T., Violence, Ritual and the Wari Empire. A Social Bioarchaeology of Imperialism in the Ancient Andes, Gainesville 2012.

Urrutia J., Aquí nada ha pasado. Huamanga siglos XVI-XX, Lima 2014.

Yamada G., Patrones de migración interna en el Perú reciente, [w:] C. Garavito, I. Muñoz Portugal (red.), Empleo y protección social, Lima 2014, s. 91-124. Yanama celebra aniversario en medio de carencias, "Correo", 12.03.2017, https://diariocorreo.pe/edicion/ayacucho/yanama-celebra-aniversario-en-medio-de-carencias-736689/ (dostęp: 22.07.2021).

Zapata Velasco A., Pereyra Chávez N., Rojas Rojas R. (red.), Historia y cultura de Ayacucho, Lima 2010.

Zevallos Trigoso N., Desplazamientos Internos en el Perú, Lima 2015. 